\title{
Late Miocene Indarctos punjabiensis atticus (Carnivora, Ursidae) in Ukraine with survey of Indarctos records from the former USSR
}

\author{
Gennady F. Baryshnikov
}

\begin{abstract}
The detailed description of the latest Miocene (MN 13) maxillary fragment with P4-M2 of Indarctos bear from Ananiev in the southern Ukraine is given. The specimen is assigned to the subspecies I. punjabiensis atticus (Weithofer, 1888), comb. nov. A pronounced similarity revealed in tooth proportions and size between I. p. atticus and I. oregonensis from the North American late Miocene suggests $I$. oregonensis to be only a subspecies: I. punjabiensis oregonensis Merriam, Stock et Moody, 1916, comb. nov. The Indarctos records from the territory of the former USSR are reviewed.
\end{abstract}

KEY-WORDS: Indarctos, Miocene, Europe.

Gennady F. Baryshnikov [G_Baryshnikov@mail.ru], Zoological Institute, Russian Academy of Sciences, Universitetskaya nab. 1, Saint Petersburg 199034, Russia.

\section{Indarctos punjabiensis atticus (Carnivora, Ursidae) из позднего миоцена Украины и обзор находок Indarctos из бывшего СССР}

\section{Г.Ф. Барышников}

\begin{abstract}
РЕЗЮМЕ. Дано детальное описание фрагмента верхней челюсти с Р4-М2 медведя рода Indarctos из местонахождения Ананьев на юге Украины, датированного концом миоцена (MN 13). Образец отнесен к подвиду I. punjabiensis atticus (Weithofer, 1888), comb. nov. Отмечено большое сходство пропорций и размеров зубов у I. p. atticus и I. oregonensis из позднего миоцена Северной Америки, позволяющее предположить, что I. oregonensis является лишь подвидом: I. punjabiensis oregonensis Merriam, Stock et Moody, 1916, comb. nov. Приведен обзор находок Indarctos c территории бывшего CCCP.
\end{abstract}

КЛЮЧЕВЫЕ СЛОВА: Indarctos, миоцен, Европа.

\section{Introduction}

The genus Indarctos Pilgrim, 1913 comprises extinct bears of moderate to large size, with short muzzle and plantigrade limbs. It demonstrates the Holarctic range. In the late Miocene, Indarctos has been distributed in Eurasia, northern Africa and North America (Petter \& Thomas, 1986; Hunt, 1998).

Thenius (1959) has revised the composition of Indarctos, establishing two species for Eurasia: a comparatively small $I$. arctoides (Depéret, 1895) with subspecies $I$. a. arctoides and $I$. a. vireti Villalta et Crusafont Pairó, 1943, and a large I. atticus (Weithofer, 1888 ex Dames) with subspecies I. a. atticus, I. a. punjabiensis (Lydekker, 1884), and I. a. lagrelii (Zdansky, 1924). In addition,I. oregonensis Merriam, Stock et Moody, 1916 was described for North America. In this work, Thenius failed to ascertain the status ofI. anthracitis (Weithofer, 1888), which was known by a single specimen of right mandible from Monte Bamboli (MN 13) in Italy.

Thenius' classification has been accepted by Petter \& Thomas (1986). However, other authors recognize three Indarctos species in Europe, stratigraphically following one another (I. vireti, I. arctoides, I. atticus) (Crusafont Pairó \& Kurtén, 1976; Beaumont, 1988; Roth \& Morlo, 1997; Ginsburg, 1999).
Most researchers accept a single species for the Turolian of Eurasia, which was cited with different authorship: I. atticus (Dames, 1883), I. atticus (Dames in Weithofer, 1888), I. atticus (Weithofer, 1888 ex Dames), I. atticus (Weithofer, 1888).

Dames (1883: 132) described a fragment of mandible from Pikermi as Hyaenarctos sp. Later, Weithofer (1888: 231, Taf. 12, figs. 1, 2) established a new species, Hyaenarctos atticus, using the same material. Despite Weithofer (1888: 233) mentioned that he used the unpublished name proposed by Dames, he has to be treated as the author of this species, being the first who has published a suitable description (International Code of Zoological Nomenclature, 1999, Article 50.1).

Thenius (1959) considered I. punjabiensis from Hosnot, Siwaliks as a subspecies ofI. atticus, an opinion which has been widely accepted (Petter \& Thomas, 1986; Roth \& Morlo, 1997; Roussiakis, 2001). As it is quite obvious that in such a case the species name $I$. punjabiensis (Lydekker, 1884) has the priority of $I$. atticus (Weithofer, 1888), the subspecies from Pikermi should be designated to I. punjabiensis atticus (Weithofer, 1888), comb. nov.

I accept two Indarctos species for Eurasia, considering I. punjabiensis as a direct descendant of earlier and more primitive I. arctoides. Petter \& Thomas (1986) 


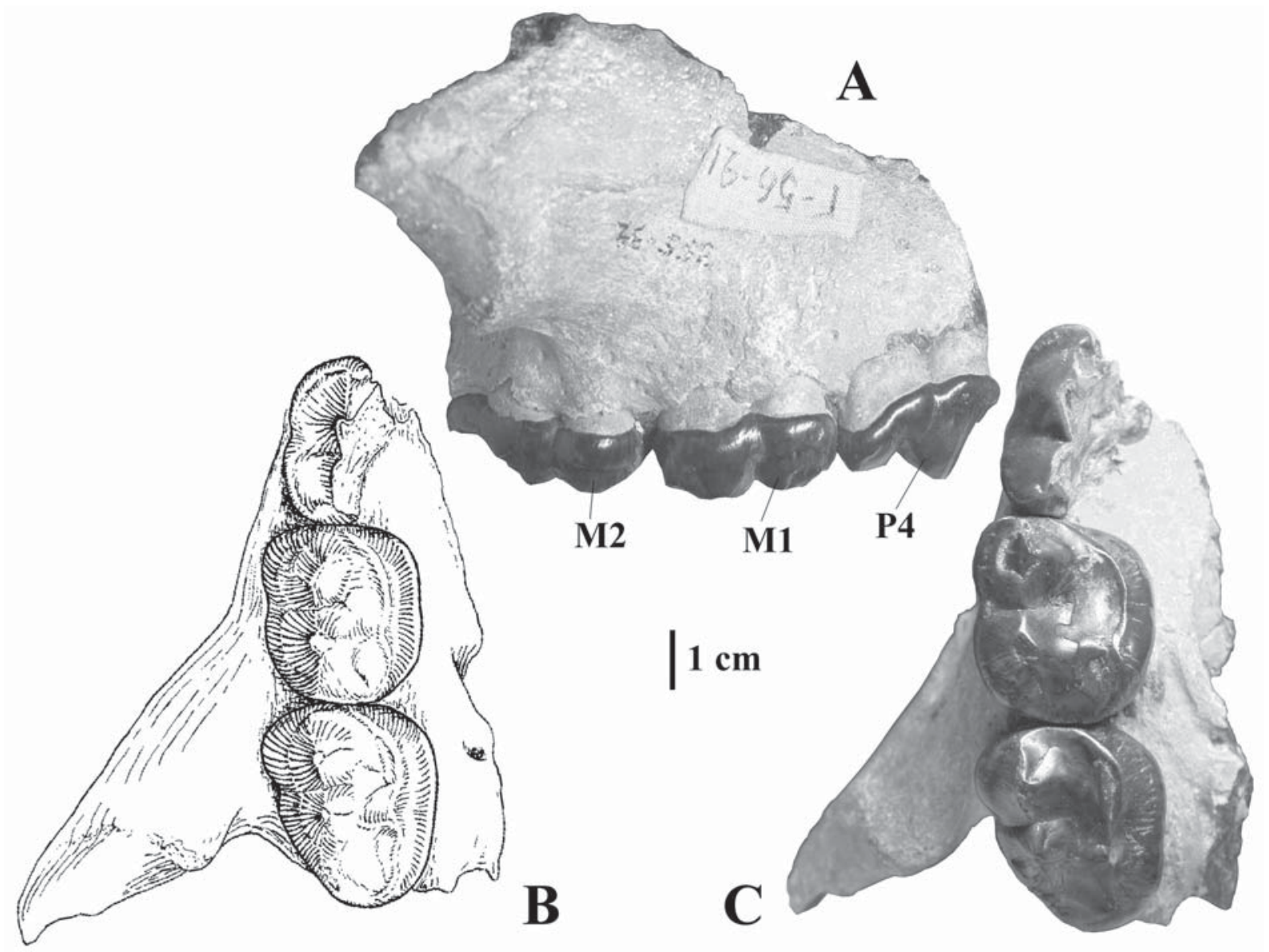

Figure 1. Right maxilla with P4-M2 of Indarctos punjabiensis atticus from Ananiev (PIN 355-92) in lateral (A) and ventral $(\mathrm{B}, \mathrm{C})$ views.

observed the similarity of I. anthracitis and I. arctoides. Presumably, I. anthracitis constitutes a deviated (insular?) subspecies of $I$. arctoides.

The collections on the genus Indarctos remain mostly unstudied in the republics of the former USSR with exception for Moldova (Lungu \& Chemyrtan, 1996). An old finding from the Ukraine is kept in the Paleontological Institute, Russian Academy of Sciences, Moscow (PIN). It represents a maxillary fragment, which drawing has been published and determined as Indarctos sp. (Dubrovo, 1962: fig. 235). Here I present a more detailed study of this specimen.

\section{Locality and material}

The Indarctos specimen has been found by geologist A.K. Alexeev near Ananiev City in Odessa Province in the southern part of Ukraine. Stratigraphical position of this finding is unknown. Most probably, it originates from the level (Balta layers?) where cervidsNeomegaloceros gracilis Korotkevich, 1971 and Procapreolus cf. cusanus (Croizet et Jobert, 1928) have been determined. This species association allows the locality to be dated as the latest Miocene (late Turolian, MN 13) (Vislobokova, 1990).
The material examined represents a fragment of right maxilla with P4-M2 (PIN 355-92), which retains a root of the zygomatic arch (Fig. 1). Bone substance is dense, being colored in pale gray. Tooth enamel is dark fuscous with greenish tint. The inner portion of $\mathrm{P} 4$ is missing.

For comparison, the cheek teeth M1 and M2 from the type specimen of I. arctoides (UCBL 210184) in the collection of Université Claude-Bernard Lyon 1 (UCBL), Villeurbanne, France, have been used.

Tooth dimensions were taken with dial calipers with accuracy up to $0.1 \mathrm{~mm}$.

\section{Description}

The thick anterior root of the zygomatic arch is situated between centers of M1 and M2. Its height is $48.5 \mathrm{~mm}$, width is $22 \mathrm{~mm}$. The ridge-shaped lower edge of the anterior zygomatic root turns into a widening similar to that in Arcto$d u s$. A trace of the infraorbital canal implies that it was long $(46 \mathrm{~mm})$ and opened above the posterior part of $\mathrm{P} 4$, as in I. $p$. atticus from Samos (Helbing, 1932: Taf. I, 3) and Samos II (Thenius, 1959: Abb. 5). The posterior palatine foramina (major and minor) are observed. The major opening is large, locating near the middle of $\mathrm{M} 1$, like in other Indarctos specimens. 
TABLE 1. Size of ChEEK teEth IN INDARCtOS.

\begin{tabular}{|c|c|c|c|c|c|}
\hline \multirow[b]{2}{*}{ Measurements, mm } & \multicolumn{2}{|c|}{ I. punjabiensis atticus } & \multicolumn{2}{|c|}{ I. punjabiensis oregonensis } & \multirow{2}{*}{$\begin{array}{c}\text { I. arctoides } \\
\text { Montredon, } \\
\text { France, UCBL } \\
210184\end{array}$} \\
\hline & $\begin{array}{l}\text { Ananiev, } \\
\text { PIN 355-92 }\end{array}$ & $\begin{array}{c}\text { Samos (Helbing, } \\
\text { 1932; Thenius, 1957) }\end{array}$ & $\begin{array}{c}\text { Rattlesnake, } \\
\text { Oregon (Merriam } \\
\text { et al., 1916) }\end{array}$ & $\begin{array}{l}\text { Withlacoochee } \\
\text { River, Florida } \\
\text { (Wolff, 1978)* }\end{array}$ & \\
\hline Length of P4-M2 & 92.6 & - & & 97.1 & \\
\hline \multicolumn{6}{|l|}{ P4 } \\
\hline Greatest length & 30.7 & $29.1,29.5$ & 31.7 & 33.2 & \\
\hline Length of paracone & 19.8 & - & - & 19.2 & \\
\hline \multicolumn{6}{|l|}{ M1 } \\
\hline Greatest length & 31.6 & $29.0,28.3$ & & 34.5 & $>24.1$ \\
\hline Length of frontal part & 15.5 & - & & 16.2 & - \\
\hline Length of caudal part & 16.0 & - & & 18.2 & - \\
\hline Length of paracone & 11.1 & - & & 12.7 & 11.8 \\
\hline Length of metacone & 10.4 & - & & 15.3 & 9.3 \\
\hline Greatest width & 27.7 & $28.5,26.2$ & & 31.7 & 22.8 \\
\hline \multicolumn{6}{|l|}{ M2 } \\
\hline Greatest length & 35.3 & $34.0,30.0$ & 35.3 & 35.8 & 28.9 \\
\hline Length of paracone & 13.5 & - & 13.8 & 15.5 & 11.3 \\
\hline Length of metacone & 13.7 & - & - & 12.1 & 8.2 \\
\hline Width of frontal part & 27.2 & $26.0,26.5$ & 26.8 & 29.6 & 20.8 \\
\hline Width of caudal part & 21.3 & - & 17.6 & 18.9 & 17.5 \\
\hline \multicolumn{6}{|l|}{ Index (\%) } \\
\hline Width M2/length M2 & 77.0 & $76.5,88.3$ & 75.9 & 82.7 & 72.0 \\
\hline
\end{tabular}

* Measurements taken on Wolff's figure 2.

The cheek teeth are large, their labial edges forming an arch. The tooth row P4-M2 is $92.6 \mathrm{~mm}$ in length (Tab. 1). The cusps in M1 and M2 are worn apically. In M1 the lingual cusps are worn; a large horizontal facet of wear resembles that in recent Ursus arctos L., 1758 as well as in other bears consuming vegetarian food.

The ratio between the length of each tooth in the row P4M1-M2 and a total row length (31.4-32.4-36.2\%) differs from that of I. p. atticus from Samos II (33.6-32.2-34.2\%), which I have calculated using the measurements of Thenius (1959), in a relatively shorter carnassial tooth P4 in PIN 355-92, whereas M2 is longer.

In $\mathrm{P} 4$ the lingual portion is missing. The tooth is high (15.6 $\mathrm{mm}$ ); its height is more than half of its greatest length. A small parastyle is developed; it is placed close to the paracone and shifted lingually relative to the anterior ridge of the later cusp. The paracone occupies a greater part of the labial crown side. It markedly exceeds the metastylar blade (metacone + metastyle) in height and separated from it by the carnassial notch. The shearing blade constitutes $35.2 \%$ of the tooth greatest length. The cingulum is well developed in the anterior half of the crown, being weakly marked in its labial edge. The tooth has three roots.
M1 is nearly quadrate, being only slightly longer than wide. The outer and inner sides of the crown are approximately equal in length. The tooth is wider in the anterior part than in posterior one. The paracone and metacone have an outline of high three-edged domes. These cusps are similar in basal area and height. The parastyle is miniature, the metastyle is longer. The inner wall of the paracone is steep, that of the metacone is gently sloping. The lingual cusps are heavily worn. The trigon basin is in the shape of a narrow longitudinal valley restricted anteriorly by the preprotocrista. The labial cingulum is weakly developed. The lingual cingulum is expanded anteriorly into a shelf, forming the anterolingual corner of the tooth. The enamel below the cingulum is ornamented with vertical crenulations.

M2 is somewhat longer than M1. The crown is widened in the anterior part, however the tooth is longer than wide. The parastyle is absent. The paracone and metacone are high three-edged cusps; the paracone is larger than the metacone. The trigon basin is narrow, without crenulations. M2 is in the initial stage of wear, so that the ridge-like protocone and conical metaconule placed behind it may be distinguished. The talon is small, in shape of a plateau declined posteriorly. 

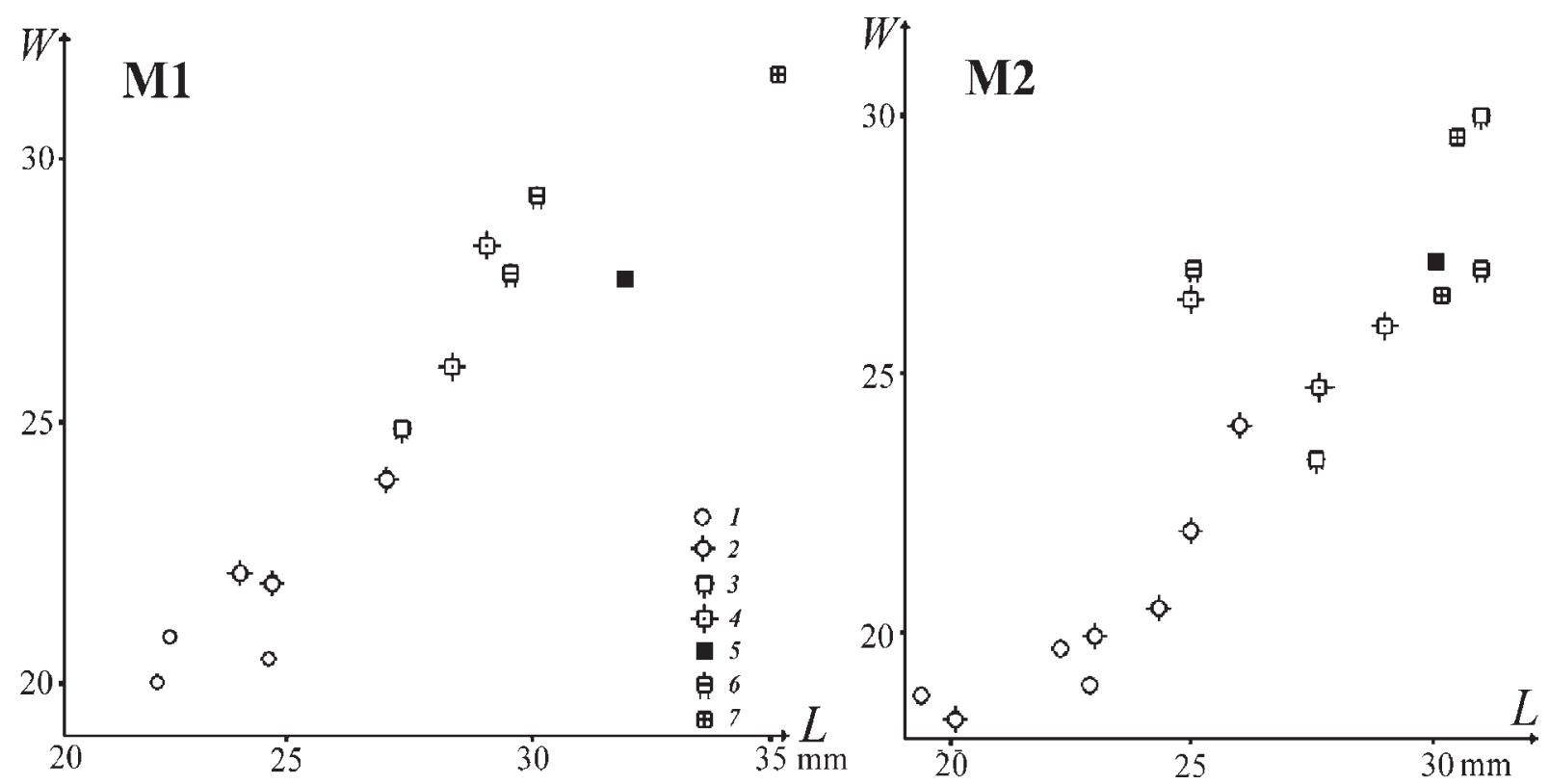

Figure 2. Length (L) and width (W) of M1 and M2 of the Indarctos specimens (from Petter \& Thomas (1986) with modifications).

1 - I. arctoides vireti (Can Llobateres, Otovaska), 2 - I. arctoides arctoides (Montredon, Orignac, Gau-Weinheim, Kücükçekmeçe), 3 I. punjabiensis lagrelii (Paote), $4-$ I. punjabiensis atticus (Samos, Dorn-Dürkheim 1), $5-$ I. punjabiensis atticus (Ananiev), $6-I$. punjabiensis punjabiensis (Hasnot), 7 - I. punjabiensis oregonensis (Rattlesnake, Withlacoochee River).

A poorly distinct ridge runs along its margin. The weak labial cingulum is developed at the bases of paracone and metacone. The lingual cingulum is complete, widened near the protocone. Vertical crenulations are present on the enamel.

\section{Comparison}

The specimen PIN 355-92 may be assigned to the genus Indarctos by the following characters: $\mathrm{P} 4$ with a small parastyle, M1 shorter than M2, and M2 with a talon developed that makes this tooth longer than wide. In contrast, the genus Agriotherium Wagner, 1837, as well characterizing by robust cheek teeth, has larger parastyle of P4, M1 longer than M2, and talon of M2 undeveloped making this tooth wider than long (Hendey, 1980).

Dimensions of the Ananiev cheek teeth pronouncedly exceed those of I. arctoides (Tab. 1; see also Crusafont Pairó \& Kurtén, 1976). In a scatter plot diagram, demonstrating ratio between length and width for M1 and M2 (Fig. 2), PIN 355-92 is distributed into the space of I. p. atticus from Samos and I. p. punjabiensis from Hosnot, Siwaliks.

Therefore, judging from the characters of the cheek teeth, PIN 355-92 belongs to I. punjabiensis. The dimensions of its P4 and M2 are virtually the same as in the type material of $I$. oregonensis described from Rattlesnake Formation, East Fork of John Day River in Oregon (Merriam et al., 1916: figs. 4, 8, 9). In another specimen ofI. oregonensis from Withlacoochee River in Florida, these teeth are larger (Wolff, 1978: fig. 2). However, I failed to find any sufficient morphological difference between those specimens and the specimen from Ananiev, with except of more robust parastyle of P4 in the North American individuals. On the other hand, the later character is variable, which makes it unsuitable for species diagnostics. Thus it seems quite possible that a single species, I. punjabi- ensis, inhabited Eurasia and North America in the latest Miocene. This Eurasian aborigine might migrate to North America forming in middle Hemphillian (MN 13; see Hunt, 1998) the subspecies I. $p$. oregonensis Merriam, Stock et Moody, 1916, comb. nov.

I. punjabiensis pronouncedly varies in cheek teeth dimensions (Petter \& Thomas, 1986), that might be explained by considerable size distinctions between males and females. In the greatest length of M2, PIN 355-92 exceeds the samples from Samos and Samos II in Greece (Helbing, 1932; Thenius, 1959), as well as from Dorn-Dürkheim 1 in Germany (Roth \& Morlo, 1997). The Ananiev specimen could be assigned to a male.

Indarctos reveals some tendencies to evolutionary modification of upper cheek teeth. Among the European representatives, the increasing of cheek teeth size is traced from early subspecies I. a. vireti (Can Llobateres) to I. a. arctoides (Montredon, Orignac), resulting in robust teeth in I. p. atticus (Samos) (Crusafont Pairó \& Kurtén, 1976). The largest cheek teeth are observed in the latest North American subspecies $I$. p. oregonensis (see Tab. 1).

M2 is changed in proportions. In I. a. vireti, the tooth is considerably narrow. Its greatest width constitutes in average $70.15 \%(\mathrm{n}=2)$ of its greatest length. M2 becomes wider in $I$. a. arctoides $(75.13 \%, \mathrm{n}=3)$, reaching the maximum width in younger bears, I. p. atticus $(80.20 \%, \mathrm{n}=3), I$. p. punjabiensis $(77.1 \%, \mathrm{n}=1)$, and $I$. $p$. oregonensis $(78.63 \%, \mathrm{n}=3)$ (Pilgrim, 1914; Merriam et al., 1916; Crusafont Pairó \& Kurtén, 1976; Wolff, 1978; Roth \& Morlo, 1997). Extremely narrow tooth $(71.8 \%, \mathrm{n}=1)$ was observed in subspecies $I$. $p$. lagrelii from China (Paote) (Zdansky, 1924). The recent ursids are characterized by development of the elongated talon of M2 formed by expansion of the posterior cingulum into a shelf. It has first appeared in latest species of the genus Ursavus Schlosser, 1899 , provoking relative decreasing of M2 width in U. dep- 
ereti Schlosser, $1902(71.70 \%, \mathrm{n}=2)$ from the late Miocene as compared with that in U. elmensis Stehlin, 1917 (95.78\%, $\mathrm{n}=5$ ) from the early Miocene (Dehm, 1950; Crusafont Pairó \& Kurtén, 1976). Controversially, in Indarctos, M2 relatively increases its width as a result of the talon reduction, the youngest representatives demonstrating the widest M2. The talon reduction is most pronounced in the genus Agriotheri$u m$, in which the tooth width commonly exceeding the length.

Hendey (1980) pointed out that the parastyle of P4 is stronger developed in stratigraphically younger representatives of Indarctos. Indeed, the parastyle is absent in archaic $I$. a. vireti, originating in $I$. a. arctoides and enlarging in $I$. $p$. atticus from Samos and Concud (Matthew, 1929; Helbing, 1932; Crusafont Pairó \& Kurtén, 1976); it is especially robust in I. p. punjabiensis from Hosnot, Siwaliks (Pilgrim, 1914) and I. oregonensis from North America (Merriamet al., 1916; Wolff, 1978)

The PIN 355-92, corresponding to tendencies of the Indarctos evolution in large size of teeth, comparatively wide $\mathrm{M} 2$, and rather developed parastyle of P4, may be attributed to the subspecies I. p. atticus. In Western Europe, this subspecies is known up to the middle Turolian (Concud, Valdecebro 5 in Spain, MN 12) (Roth \& Morlo, 1997); therefore the find from Ananiev (MN 13) could be its latest record from Europe.

\section{Survey of Indarctos specimens from the former Soviet Union}

The record of Indarctos fossils from the former USSR territory is scant.

The oldest record is a left maxilla with C1-M2 from Otovaska quarry near Kishinev in Moldova Republic, which was described as a new species, Indarctos sarmaticum (Lungu \& Chemyrtan, 1996: 185). The Otovas$\mathrm{ka}$ theriofauna includes Tetralophodon longirostris (Kaup, 1832),Aceratherium cf.incisivum (Kaup, 1832), Miotragocerus pannoniae (Kretzoi, 1941) that makes it possible to attribute the specimen to middle Bessarabian $=$ early Vallesian (MN 9). The biostratigraphical dating is ascertained by paleomagnetic evidence establishing the age of locality as 11.0-10.8 Ma (Pevzner et al., 1987).

The cheek teeth are small (length/width, mm: P4 21.2/17.2, M1 22.3/20.0, M2 24.5/18.5). The anterior premolars are slightly reduced. P2-3 are two-rooted. P4 possesses a very small parastyle. M2 is elongated; the width constitutes $76 \%$ of its greatest length. Such a dentition corresponds to that of $I$. arctoides vireti from Can Llobateres (Crusafont Pairó \& Kurtén, 1976). Despite I. sarmaticum Lungu et Chemyrtan, 1996 is somewhat different in presence of a very small parastyle on $\mathrm{P} 4$ and comparatively wide M2, the species should be considered as a junior synonym of $I$. a. vireti.

All other finds are markedly younger. The incomplete skeleton of Indarctos has been found in Pavlodar (Gusinyi Perelet) in the northern Kazakhstan (Leonid Gaiduchenko, personal communication). The age of the locality was determined as the late Turolian (MN 13) (Vislobokova et al., 2001). This material is still unstudied, however the stratigraphical position suggests its assigning to I. punjabiensis.

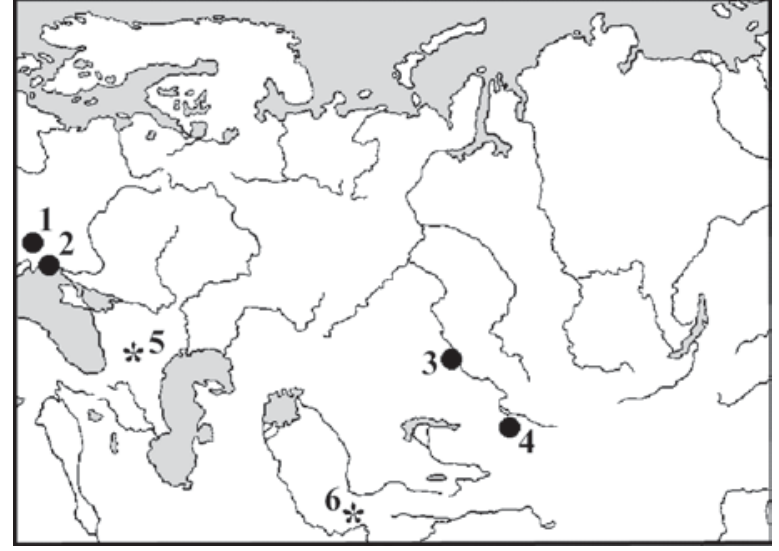

Figure 3. Distribution of Indarctos in the former USSR territory.

Black circles indicate the reliable finds, asterisks denote doubtful finds. Indarctos arctoides vireti: 1 - Otovaska; Indarctos punjabiensis atticus: 2 - Ananiev; Indarctos sp. (cf. punjabiensis): 3 Pavlodar, 4 - Kalmakpai; Indarctos sp.: 5 - Kosyakino (Agriotherium?), 6 - Dzhetymtau.

Indarctos sp. has been recorded from Kalmakpai in the eastern Kazakhstan (Tleuberdina, 1988: 55). The Neogene deposits at Kalmakpai show normal magnetic polarity (Pevzner et al., 1982). Recent investigations of fossil mammals from this locality attribute it to the latest Miocene (MN 13) (Vislobokova et al., 2001).

Thus, the genus Indarctos is restricted to the southern regions of former USSR (Fig. 3), where its representatives were recorded from the early Vallesian (Otovaska) and late Turolian (Ananiev, Pavlodar, Kalmakpai).

Some data from published sources report the later finds of Indarctos. A right mandible (PIN 225-253) from Kosyakino in Northern Caucasus with the almost complete set of cheek teeth was figured in occlusal view and assigned to Indarctos sp. (Dubrovo, 1962: fig. 236). I was failed to examine this specimen. As a published drawing demonstrates, $\mathrm{m} 2$ is almost as long as $\mathrm{m} 1$, the metaconid of $\mathrm{m} 1$ is robust and shifted posteriorly that is characteristic of the genus Agriotherium. The entoconid of $\mathrm{m} 1$ is single. It is unclear from illustration if any supplementary cusplet is placed between protoconid and hypoconid that is typical of Indarctos (Helbing, 1932: fig. 3). The prehypocristid on $\mathrm{m} 1$ is directed to the labial edge of protoconid that is not corresponding to its location inAgriotherium (Qiu \& Schmidt-Kittler, 1983). These peculiarities preclude exact attribution of PIN 225-253, but it rather probably belongs to the genus Agriotherium.

The age of this find is uncertain. Recently, Kosyakino locality has been dated as early Pliocene (MN 15) (Vislobokova et al., 2001). However the complex of alluvial depositions in this locality probably consists of several stratigraphical levels (Gabunia, 1959; Vereshchagin, 1959). The lowest level may contain reworked Miocene material that is testified by presence of Amblycastor cancasicus (Argyropulo, 1939) and Dicerorhinus orientalis (Schlosser, 1921) in Kosyakino fauna. 
Dicerorhinus orientalis is the Asian analogue of the European Dihoplus schleiermacheri (Kaup, 1832), occurring in Europe till the end of Turolian (Guérin, 1980).

Indarctos $\mathrm{sp}$. has also been mentioned in the faunistic list of the Dzhetymtau locality in Tajikistan (PIN 3748 , determination of V.I. Zhegallo), being ascribed to the Pliocene (Dmitrieva \& Nesmeyanov, 1982: 95). Because of the young age of this find it is necessary to verify its attribution to Indarctos.

Summarizing, it should be noted that presence of Indarctos in the Pliocene is not reliably documented still.

\section{Conclusions}

The genus Indarctos comprises two species. I. arctoides (Depéret, 1895) was found in Europe, northern Africa and Turkey, dating as the Vallesian (MN 9-11). I. punjabiensis (Lydekker, 1884) known from the Turolian (MN 10-13) had a Holarctic range, occurring in Europe, northern Africa, in the central, southern and eastern parts of Asia, and in North America.

I. punjabiensis distinguishes from I. arctoides in several derived characters of upper dentition: cheek teeth larger, anterior premolars P2-3 single-rooted and reduced in size, parastyle of P4 well developed, M2 comparatively wide.

Both species have been recorded from the territory of the former USSR.I. arctoides is known only from one locality, whereas I. punjabiensis was distributed from the southern part of Ukraine to eastern Kazakhstan.

I. punjabiensis has been reconstructed as a very large bear, reaching $500 \mathrm{~kg}$ (Roth \& Morlo, 1997). Its forelimb bones are very similar to those of recent $U$. arctos (Roussiakis, 2001) that suggest resemblance in the locomotion and mode of life in both bears. Judging from the dental morphology and tooth wear, I. punjabiensis has been omnivorous animal consuming largely plant food. It inhabited various, mainly savanna like landscapes. The palaeogeographic reconstruction based on the Ananiev assemblage of ungulates has indicated the presence of open territories with shrub thickets along the banks of rivers and lakes (Korotkevich, 1988). The large size, omnivory, and adaptation to various habitats have allowed I. punjabiensis to migrate through the Beringia to North America.

ACKNOWLEDGEMENTS. I thank Dr. A. Agadjanyan, Dr. I. Vislobokova, Dr. E. Mashchenko (Moscow) and Prof. C. Guérin (Lyon) for access to museum collections under their care. Dr. V. Eisenmann (Paris), Dr. A. Monguillon-Douillet (Lyon), Dr. R. O'Leary (New York) and A. Rezvyi (St. Petersburg), helped me in obtaining necessary photocopies. Mrs. G. Baranova has kindly drawn the Figure 1B. My wife, Svetlana Baryshnikova assisted me in preparing the manuscript. I am grateful to Dr. A. Averianov for valuable advice.

\section{References}

Beaumont G. de. 1988. Contributions à l'étude du gisement Miocène supérieur de Montredon (Herault). Les grands mammifères. 2 - Les Carnivores // Palaeovertebrata. Mémoire extraordinaire. P.15-42.

Crusafont Pairó M. \& Kurtén B. 1976. Bears and bears-dogs from the Vallesian of the Vallés-Penedés Basin, Spain // Acta Zoologica Fennica. No.144. P.1-29.

Dames W. 1883. Über das Vorkommen von Hyaenarctos in den Pliocän-Ablagerungen von Pikermi bei Athen // Sitzungsberichte der Gesellschaft naturforschender Freunde zu Berlin. Nr.8. S. 132-139.

Dehm R. 1950. Die Raubtiere aus dem Mittel-Miocän (Burdigalium) von Wintershof-West bei Eichstätt in Bayern / / Abhandlungen der Bayerischen Akademie der Wissenschaften, mathematisch-naturwissenschaftliche Klasse. Neue Folge. Hf.58. S.1-141.

Dmitrieva E.L. \& Nesmeyanov S.A. 1982. [Mammals and stratigraphy of continental Tertiary deposits of the SouthWest of Middle Asia] // Trudy Paleontologicheskogo Instituta AN SSSR. T.193. P.1-140 [in Russian].

Dubrovo I.A. 1962. [Family Ursidae] // Gromova V.I. (ed.). [Fundamentals of Paleontology. Mammals]. Moskva: Gosudarstvennoe Nauchno-Tekhnicheskoe Izdatel'stvo Literatury po Geologii i Okhrane Nedr. P.214-218 [in Russian].

Gabunia L.K. 1959. [To history of Hipparion]. Moskva: Izdatel'stvo Akademii Nauk SSSR. 571 p. [in Russian].

Ginsburg L. 1999. Order Carnivora // Rössner G. \& Heissig K. (eds.). Miocene Land Mammals of Europe. München: Verlag Dr. Friedrich Pfeil. P.109-148.

Guérin C. 1980. Les rhinocéros (Mammalia, Perissodactyla) du Miocene terminal au Pleistocene superieur en Europe occidentale: Comparaison avec les espèces actuelles // Documents des Laboratoires de Géologie Lyon. No.79. Fasc.1. P.1-421.

Helbing H. 1932. Über einen Indarctos-Schädel aus dem Pontien der Insel Samos. Nebst einem Anhang: Hyaenarctos spec. aus dem Pliocaen von Vialette (Haute-Loire) // Abhandlungen der schweizerischen palaeontologischen Gesellschaft. Bd.52. S.1-18.

Hendey Q.B. 1980. Agriotherium (Mammalia, Ursidae) from Langebaanweg, South Africa, and relationships of the genus // Annals of the South African Museum. Vol.81. No.1. P.1-109.

Hunt R.M., Jr. 1998. Ursidae // Janis C., Scott K. \& Jacobs L. (eds.). Evolution of Tertiary Mammals of North America. Vol.1. Terrestrial Carnivores, Ungulates, and Ungulatelike Mammals. Cambridge University Press. P.174-194.

Korotkevich E.L. 1988. [History of formation of Hipparion fauna in Eastern Europe]. Kiev: Naukova Dumka. 164 p. [in Russian].

Lungu A.N. \& Chemyrtan G.D. 1996. [New species of the genus Indarctos (Carnivora, Mammalia) from the Middle Sarmatian Hipparion fauna of Moldova] // Sokolov V.E. (ed.). [State of the Theriofauna in Russia and Adjacent Territories]. Moskva: Teriologicheskoe Obshchestvo. P.184-190 [in Russian, with English summary].

Matthew W.D. 1929. Critical observations upon Siwalik mammals // Bulletin of the American Museum of Natural History. Vol.56. P.437-560.

Merriam J.C., Stock Ch. \& Moody C. 1916. An American Pliocene bear // University of California Publications. Bulletin of the Department of Geology. Vol.10. No.7. P.87-109. 
Petter G. \& Thomas H. 1986. Les Agriotheriinae (Mammalia, Carnivora) néogènes de l'ancien monde presence du genre Indarctos dans la faune de Menacer (ex-Marceau), Algérie // Geobios. No.19. Fasc.5. P.573-586.

Pevzner M.A., Lungu A.N., Vangengeim E.A. \& Basilyan A.E. 1987. [Position of Vallesian localities of Hipparion fauna from Moldavia on magnetochronological scale] // Izvestiya AN SSSR. Seriya Geologicheskaya. No.4.P.5059 [in Russian].

Pevzner M.A., Vangengeim E.A., Zhegallo V.I., Zazhigin V.S. \& Liskun I.G. 1982. [Correlation of late Neogene beds of Central Asia and Europe on the basis of paleomagnetic and biostratigraphical data] // Izvestiya AN SSSR. Seriya Geologicheskaya. No.6. P.5-16 [in Russian].

Pilgrim G.E. 1914. Further description of Indarctos salmontanus Pilgrim, the new genus of bear from the Middle Siwaliks, with some remarks on the fossil Indian Ursidae // Records Geological Survey of India. Vol.44. Pt.3. P.225-233.

Qiu Z. \& Schmidt-Kittler N. 1983. Agriotherium intermedium (Stach, 1957) from a Pliocene fissure filling of Xiaoxian county (Anhuei province, China) and the phylogenetic position of the genus // Palaeovertebrata. T.13. No.3. P.65-81.

Roth C.H. \& Morlo M. 1997. Die Raubtiere (Mammalia, Carnivora) aus dem Turolium von Dorn-Dürkheim 1 (Rheinhessen). Teil 2: Ursidae // Courier ForschungsInstitut Senckenberg. Bd.197. S.49-71.

Roussiakis S. 2001. Postcranial remains of Indarctos atticus (Ursidae, Mammalia) from the classical locality of Pikermi (Attica, Greece), with a description of the front limb
// Senckenbergiana lethaea. Bd.81. S.347-358.

Thenius E. 1959. Indarctos arctoides (Carnivora, Mammalia) aus dem Pliozän Österreich nebst einer Revision der Gattung // Neues Jahrbuch für Geologie und Paläontologie, Abhandlungen. Bd.108. Hf.3. S.270-295.

Tleuberdina P.A. 1988. [Main localities of Hipparion fauna in Kazakhstan and their biostratigraphical correlation] // Materialy po Istorii Fauny i Flory Kazakhstana. T.10. Alma-Ata. P.38-73 [in Russian].

Vereshchagin N.K. 1959. [The Mammals of the Caucasus: A History of the Evolution of the Fauna]. Moskva-Leningrad: Izdatel'stvo Akademii Nauk SSSR. 704 p. [in Russian].

Vislobokova I.A. 1990. [Fossil deers of Eurasia] // Trudy Paleontologicheskogo Instituta AN SSSR. T.240. P.1208 [in Russian with English summary].

Vislobokova I.A., Sotnikova M.V. \& Dodonov A.E. 2001. Late Miocene - Pliocene mammalian faunas of Russia and neighbouring countries // Bullettino della Società Paleontologica Italiana. Vol.40. No.2. P.307-313.

Weithofer A. 1888. Beiträge zur Kenntnis der Fauna von Pikermi bei Athen // Beiträge zur Paläontologie und Geologie Österreich-Ungarn und des Orients. Bd.6. Hf.3. S.225-292.

Wolff R.G. 1978. Function and phylogenetic significance of cranial anatomy of an early bear (Indarctos) from Pleistocene sediments of Florida // Carnivore. Vol.1. No.3/4. P.1-12.

Zdansky O. 1924. Jungtertiäre Carnivoren Chinas // Palaeontologia Sinica. Series C. Vol.2. Fasc.1. S.1-149. 